\title{
21 世紀に向けての健診のハードル
}

一医療情報学の立場から一

武田裕

慣用的に使用されてきた病名である「成人病」 が，新たに「生活習慣病」という概念に置き換え られつつある。この変化に象徵されるように, 21 世紀社会ではこれまでの健診システムが主な対象 としてきた, 疾患の早期発見・早期治療 (二次予 防）の目標をさらに進めて, 疾病の一次予防に重 点を置くことが強く求められるであろう。この新 たな目標を実現するためのハードルを越えるため に, 情報収集, 情報処理, 指導 - 治療, 情報伝達 と記録の各要素が一つのシステムとして構築され (図 1), 各要素ごとに以下の課題が解決されねば ならないことを医療情報学的立場から提言する。

1) デー夕収集：生活習慣に即した健診デー夕 を得るために，健診における問診項目の見直し， 特に食事，運動，ストレスなど日常生活に関する 定量的なデー夕の収集方法を検討する必要があ る。血圧・心拍数など生理機能に関する行動科学 的データの取得方法（携帯型, 無線型データ収集 装置）など新技術の開発や既存の優れた検查手法 の導入など現行の健診項目の再評価, 見直しが求 められる。

2 ）デー夕処理：迅速かつ正確な健診デー夕処 理を行い良質な健診機能を維持するとともに，受 診者の意思決定を有効に支援するツールを提供す る。そのためには, 問診デー夕直接入力, 医師所 見の発生源入力，検査機器とのオンライン処理な ど健診業務処理の高度化の推進, 質的に多様かつ 大量なデー夕の処理方法を再構築する必要があ る。

Hurdle for AMHTS in the 21st Century ; -An Outlook from Medical Informatics大阪大学医学部附属病院医療情報部
通常実施されている疾病の早期発見を主体とし た健診結果報告のみならず, 疾病一次予防志向の 健診結果出力, より分かりやすい表現形式（グラ フ・図形・音声・動画の利用), 個性を重視した生 活指導プログラムなど受診者の生活習慣に介入し 意志決定を支援するツールを開発すべきである。

さらに二次予防の精度をさらに向上させるた め, 長期間反復受診者には, 蓄積された過去の データの有効利用, 例えば個人正常 (参照) 值に よるより検出力の高いスクリーニング方法も開 発, 活用が期待される。

3 ）健診デー夕記録：健診記録は, 個人の健康 管理により有効に利用できるよう環境を整備すべ きである。近年実現に向けて開発が進んでいる電 子カルテ (EPR, Electronic Pateint Record) と の連携, PHD(Personal Health Database)をカー ド型媒体に出力して常時携帯させ, 緊急時を含む 医療施設受診時の診療情報提供を行うこと, 職域 単位での健康管理を支援するため同一事業所の データを一括して事業所の健康管理センターに配 信するなど新たな健診記録の利用方策を確立すべ きである。医用画像・音声を含むマルチメディア・ データベースの構築, 目的志向型のデータ保管・ 検索の実現も緊急課題である。

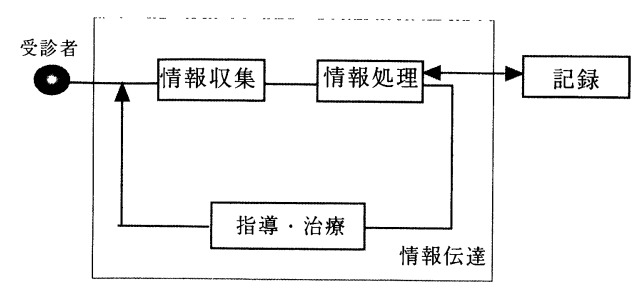

図 121 世紀に向けての健診のハードル 
なお，プライバシー保護を重視し社会的なコン センサスに基づいて，より慎重なデータ保管・検 索を行うとともに，厳格なデータ・セキュリティ 管理が行われねばならない。

4 ）デー夕通信：多くの健診システムは閉鎖的 かつ独立的に運営されてきたが, 医療・福祉・保 健連携に積極的に関与が求められる。デー夕通信 技術の進歩により, 専用回線利用の医療・福祉・ 保健ネットワークによる受診者健診データなどの 共同利用，精密検査フォローアップなど，関連施 設とのより密接な関係をネットワーク上で構築す ることが期待される。また，通信とデータベース 検索を同時に可能とするネットワーク・コンピュー タとデータウエア・ハウスの概念は, 健診システ ム・データの遠隔地からの検索に特に有用であり, 受診者へのサービスの一環として前向きに考慮さ れねばならない。

これまでは技術的に困難であった一般住民を対 象とした疾病予防教育, 国内外への健診システム 紹介などをインターネット上のコンテンツを利用 して実現することが可能となりつつある。より オープンな情報受発信機能を整備することは 21 世紀の総合健診システム（AMHTS）の役割であ り，インターネットなど情報通信技術の活用を推
進すべきである。

社会のニーズの変化に伴い, 健診システムが医 療, 疾病予防, 保健との連携に果たす役割はこれ まで以上に大きくなりつつある。その期待に応え るために, より積極的に医療情報学的手法・情報 処理通信技術を導入し，これまでの自己完結型の 健診システムがネットワーク型に移行すること が, 21 世紀に向けての最大の作業目標であろう。

そして, 健診システムは新しい医学・医療に貢 献する役割を担うべきである。多施設の健診デー 夕を対象としたメガ・トライアルによる予防医学 的研究が最も優先される。生活習慣病の制御が 21 世紀の医学・医療の重要な課題であるが, その予 防に関するデータベースは，医療施設よりも健診 施設に蓄積されている。これらのデータと長期 フォローアップデータを結合して, 情報科学的解 析ができれば，これまでの医学が有し得なかった 生活習慣と疾病発症に関する新しい知見が得られ るはずである。健診データの二次有効利用を重視 した健診システム・ネットワークの実現が 21 世紀 社会への最大の貢献となり得るものであり，いま 健診システムが越えねばならない最大のハードル である。 